\title{
Activating the local community (theoretical grounds and examples of good practices of the revival of the idea of active neighbourhood)
}

\section{KEYWORDS}

local community, activation, potential, neighbourhood, initiatives

\begin{abstract}
Słupska Kamila, Activating the local community (theoretical grounds and examples of good practices of the revival of the idea of active neighbourhood). Culture - Society Education no. 1(17) 2020, Poznań 2020, pp. 265-277, Adam Mickiewicz University Press. ISSN 2300-0422. DOI 10.14746/kse.2020.17.11.2
\end{abstract}

This paper focuses on the issue of activating the local community, including its conditions and manifestations, and putting strong emphasis on the category of community potential, which is a multifaceted and dynamic phenomenon, contributing to changes in various areas of social life. Particular attention was paid to neighbourhood activity and its stimulation, including related initiatives, the importance of which was highlighted, while selected examples of good practices, implemented both within projects, organised campaigns, as well as spontaneous individual actions were brought up..

\section{Local community - context of activation and development (introduction)}

The category of "local community activation and development," also referred to as "community development," described by Zbigniew T. Wierzbicki as a sub-discipline

* ORCID https://orcid.org/0000-0003-4203-8544. 
of the city and countryside, as well as social pedagogy, covers a number of issues (Wierzbicki, 1987: 313). It can be analysed from the point of view of four aspects: the process (with the dominant category of change), - the methodology (the methods of action used and their effectiveness), - the programme (tasks to be carried out, definition of key directions, most often pertaining to the continuum, spanning from one-off or occasional actions, through the construction of more permanent structures, to campaigns and structures requiring considerable effort), - the social movement (a collective undertaking which in its essence serves to establish a new order) (Wierzbicki, 1973: 24-26). The analysed issue garnered some considerable attention several decades ago for two main reasons: the growing processes of social disorganisation and disintegration, as well as the individualisation of life, coupled with the institutionalisation and segmentation of society, as well as the realisation that economic growth alone is not enough, since social activism is also equally important. Hence the three essential elements of community development constitute the participation of people and their involvement, engagement, "self-management" - which refers to voluntary participation, individual effort, mutual assistance; as well as "social change" - improvement of the living conditions of residents. All community development is based on the conviction that change in a given community should be brought about by members of said local community who get involved without being forced to do so, of their own volition, and who may hinder the development if they are unwilling to take part, devoid of certain skills, or expressing a passive attitude. That is why it is so important to take care of their pro-social preparation, as well as to properly formulate goals and design activities, so as to ensure that all parties can take ownership of them - by responding to the residents' needs, taking into account their actual capabilities (Wierzbicki, 1987: 317-320).

These foundations and the accompanying messages remain valid and actual. It is all the more worthwhile to take a careful look at the extent to which they are implemented now by superimposing the reality of contemporary functioning, which is hardly "easy" in the presented context. Thus, as Robert D. Putnam points out in his analysis of the situation in the United States, the restoration of social capital is difficult due to a number of reasons.

The shrinkage of the communities (...) took place quietly and deceitfully. We notice its effects in the tensions and cracks in our private lives and in the degradation of our public life, but the most serious effects resemble an old puzzle: 'What's missing in this picture?' Weakened social capital manifests itself in the things that have vanished almost unnoticed - neighbourhood parties and get-togethers with friends, unreflective kindness of strangers, the shared pursuit of the public good rather than a solitary quest for private goods. (Putnam, 2008: 653-654) 
At the same time, we started seeing the revival of localism, and in its current form - as Andrzej Radziewicz-Winnicki points out -

(...) apart from the nostalgic longing for existence in traditional structures of this kind of a community, one can also see the foundations of pragmatic ideology. It is manifested by emphasising the value of the benefits resulting from the active participation of an individual in such a structure and articulating potential opportunities to use all resources (both material and human) available in the local environment. (Radziewicz-Winnicki, 2008: 415)

Organising and developing the local community with the aim of its transformation or bringing about a social change to improve the functioning of communities exposed to the phenomenon of exclusion or already affected by it, or in other words, changing the quality of life of residents (Bąbska, Jordan, 2014: 46) turn out to be a key area in social welfare. A new manifestation of its active form comprises: "appreciating the role of communities in solving problems, creating programmes and projects referring to the idea of social solidarity, working on people's potential and the idea of empowerment" (Skrzypczak, 2014: 7), which is described in the OSL model by five mutually complementary and permeating dimensions - cohesion, empowerment, impact, involvement, cooperation (Bąbska, Dudkiewicz, 2014: 12).

Activating local communities therefore appears to be an extremely important and complex task, since it touches upon important spheres of life of both individuals and communities. This is the subject of this paper, in which the author analyses theoretical grounds pertaining to the issue at hand, referring, among others, to a broad category of local community potential, and recalling selected examples of good practices, implemented in the communities, concerning activities of the community organisers and strengthening of neighbourly relations. While pointing out the multi-faceted nature of the presented issue, the author focuses only on selected issues, which are important from both the pedagogical and social point of view.

\section{Local community potential}

The local community can act as an activating entity, as well as the goal of activation. The former situation occurs when it is characterised by bonds with a certain strength, power and quality (including a sense of identity and community; the recognition of its members; undertaking specific roles and tasks by them), which contributes to building social capital, and this in turn promotes the undertaking of 
various challenges in response to emerging needs. The latter situation in turn occurs when this "deeper" locality is missing, which mainly happens in urban communities, and which is caused by phenomena such as building sleeping districts with no space local communities to form around, a low level of public trust; a tendency to isolate. The list of activating entities includes local government, which has a legislative and executive apparatus, local businesses and their activities in the "internal arena," as well as their impact on the community; non-governmental organisations, which focus on and provide substantive or material support, as well as solve specific problems, enabling the development of passion; schools, which play a triple role in the context of activation $\mathrm{x}$ using activation methods in education, implementation of activation projects and the production of social capital; local parishes, with their religious and non-religious activities; families, which are intermediaries between the individual and the local community, while mirroring the problems faced by the community, as well as entities related to trade (local shops, shopping malls) (Schindler, 2010: 170-188). All of them, being part of the local system, can strengthen the overall "fitness" of the community by engaging in its active functioning and being one of the elements that create its potential.

The potential of a community is a dynamic and multifaceted phenomenon, which is why it should be analysed while taking this complexity into account. It has certain characteristics, occurring naturally with different intensity and changing (which means that it can be acquired or lost):

- a sense of identity, pertaining to a community of values, norms and visions; the concept refers to the closeness between the residents; the type and degree of this sense may vary, for example based on emotional or instrumental ties;

- engagement, or the sense of ownership that individuals, groups, organisations have when it comes to the events taking place in the community;

- ability to solve problems, or translating commitment into action;

- access to resources, which includes economic, human, material, political, internal and external resources.

It is exhibited by various entities:

- individuals, or the human capital and leadership exercised by leaders, which comprises the skills, knowledge, resources of the residents and their commitment to the local community;

- organisations (referred to above), which constitute group entities, local institutions, such as companies, service providers; local branches of larger institutions, including schools, commercial facilities; smaller organised groups, such as housing communities, local clubs, which - in the context 
described above - focus on skills related to their functioning in response to the community's needs. thus ensuring compatibility with the comprehensive local system, connected with broader systems (which has already been pointed out above);

- networks, or relationships between people, informal groups and formalised organisations, characterised by different ties within them.

It fulfils specific functions (normative and/or specialised): planning, decision making, management; production of goods and services; dissemination of information; organisation and advocacy to mobilise citizens for joint action. These purposes are also served by strategic interventions:

- leadership - focus on leaders;

- organisational development - reinforcing existing organisations or creation of new ones;

- organisation of communities - involving individual stakeholders;

- cooperation between organisations - development of relations and partnerships.

The effect is thus shaped by environmental influences (micro- and macro-structural) - security, certainty of place of residence, density of social contacts, structure of opportunities, migration movements, dynamics of relations between races and classes, division of power and resources. If successful, the community potential grows, along with a number of other measurable results in the form of better services, greater influence on decision-makers, or material well-being (Chaskin, Brown, Venkatesh, Vidal, 2007: 37 et seq.).

Community capacity building therefore contributes to change in many areas of social policy, including - according to Steve Skinner - effective public service delivery; sustainable development, ${ }^{1}$ revitalisation and entrepreneurship; regeneration of civil society; social cohesion; strong communities. The process of capacity building in groups operating in communities can be organised, as the author emphasises, based on four key categories:

- building skills (supporting the activation and activities of the community so that its members take on different roles, participate as volunteers, members of their organisations, neighbours, leaders, etc.);

- building organisations (and supporting said organisations in various situations, for example in the case of a crisis within the group or the need for a new organisational structure or improving the way of working);

${ }^{1}$ Characterised by: multisubjectivity, multidimensional and multi-capital nature. "All local capital from the social triad, namely the social, environmental and economic capital, should be used for local development" (Wolski, 2016: 91). 
- building commitment (activities, learning and change about how individuals are involved in the community and how social groups and networks involve people and contribute to local decision making),

- building equality (equal opportunities, diversity and cohesion) (Skinner, 2014: 17 et seq.).

\section{Neighbourhood initiatives}

The sense of having a support network and taking root is an important starting point for the development of a neighbourhood initiative. The question asked by Karol Mojkowski: "Who's a neighbour? Is it every person who lives in my estate or in the block of flats?" Paweł Jordan replied: "I prefer to talk about a 'conscious neighbour', an 'active neighbour' or just a 'good neighbour' in this situation. Such a neighbour is a resident who cares about their surroundings, and thinks about common space in terms of 'space to care for"' (Mojkowski, 2012: 10).

In the traditional, agrarian-rural world, the neighbourhood was an obvious form of cooperation, associated with mutual support. It was founded on the community of life situation of the residents and their mutual dependence on each other. However, the transformations, including the abolition of economic coercion and mutual relationships led to social relations developing on a different basis than before. "One is no longer existentially condemned to coexist with their neighbours, one can freely choose their relations and shape them autonomously. Thus, such an unambiguous spatial reference of the neighbourhood is also weakened, in that it may only exist if people live in near physical proximity of each other" (Sasiedztwa i mikroorganizacje..., 2009: 20). The importance of social networks is growing, the staging of neighbourhoods is taking place, on the basis of a shared lifestyle and the context has a strictly defined spatial nature; housing communities, ${ }^{2}$ housing estate experiments, organising specific activities, such as child care or transport). "Thus, the neighbourhood does not disappear - instead, it takes on new forms. Previously, it was mainly a spatial issue that had to be socially organised, and nowadays it is increasingly based on social proximity that is spatially organised" (Sasiedztwa i mikroorganizacje..., 2009: 22-24). Globalisation processes, the widespread development of electronic communication, mobility (social and geographical), espe-

\footnotetext{
2 Magdalena Szczepańska points out: "It can be assumed that the growing number of housing communities will contribute to changing the attitudes of Poles towards their immediate environment and the ways they function in it." She also adds: "However, there are doubts about whether such involvement can be called civic.” (Szczepańska, 2018: 12).
} 
cially concerning the residents of large cities, as well as their diversity have made it possible to "choose social contacts based not on spatial proximity, but on common interest or values" (Toruńczyk-Ruiz, Winiarska, 2018: 20). At the same time, as Sabina Toruńczyk-Ruiz and Aleksandra Winiarska point out, voices indicating the importance of the neighbourhood, which highlight its functions (support, antidote to the feeling of alienation, raising the quality of life, safety) gradually disappeared (Toruńczyk-Ruiz, Winiarska, 2018: 21).

According to the results of CBOS study, the vast majority of Poles (89\%) do not avoid their neighbours and contacts with them, but at the same time $65 \%$ admit to keeping their distance in these relations. In other words, they behave properly, but they avoid making these contacts too personal. Thus, we can speak of occasional and rather conventional neighbourly relations (CBOS, 2017).

Nowadays, one should highlight the positive qualities of the neighbourhood, or in other words, rediscover something that has always been a part of collective life, but which has undergone transformations over the years, a reflection of the social changes signalled above.

How does neighbourly activity now manifest itself? Is it spontaneous, triggered or guided?

Walking together, debating, watching exhibitions, backyard plein airs, festivals, workshops, neighbourhood cinema, dance parties, neighbourhood feast... these are only some suggestions. They can have a variety of bases: culture, education, sport, neighbourhood assistance and support. However, they often evolve, expanding the scope of their activities, often under the influence of their participants, who - although at first shyly and slowly - quite skilfully "take matters into their own hands," feeling at last to be the "hosts" of the space (both physically and mentally), having the power of causation. That is the best proof that the idea of "coexistence" is still alive. It is worth bringing up a few examples that point to successful initiatives.

One of them is a project that involves the implementation of artistic interventions in backyards (Wrocław). Artists, animators, designers and architects, who are active in a given place, cooperate with residents. "The aim is to try to awaken the awareness of responsibility for a space so close to people, which is treated as no man's land of sorts - abandoned, unmaintained." At the same time, the aim here is to awaken the potential in the residents and to encourage them to be active. The idea is to reach the (often only potential) audience directly with artistic activities and to let the viewers meet directly with the artists. "The aim of the artistic and animation activities is to change the face of the backyards, often far from the city centre, and yet serving as the epicentre of cultural events." These 
interventions are intended to make the residents aware of their driving force, that they can have a significant impact on their surroundings. It is not only about the transformations connected with the appearance and infrastructure of their backyard, but above all about the changes they have a chance to make (Romaszkan, 2016: 5).

One of the more interesting propositions are the "Intergenerational Neighbourhood Meetings" - a series of meetings taking place as part of the "Wrocław entrance from the backyard" project. Over the course of several months of working with the community, a series of discussions took place with officials, city activists, as well as artists, devoted to topics important to the residents, concerning: their rights, urban greenery, civic budget, history of the cinema, the housing estate council, establishing an association, order and safety in the estate. The programme was carried out using a participatory method, taking into account the needs and conclusions of residents (Kalita, 2016: 18).

Local community organisers (often employees of the social welfare sector), who simultaneously perform three tasks, turn out to be very helpful in activating the local communities and revival of the neighbourhood. These tasks, or roles, include: - an animator who stimulates the activities of communities, groups and individuals, supports grassroots initiatives; - a social network organiser, who, among other things, shows how to use the potential of social institutions, maintains communication and cooperation networks between entities; - a local planner who, among other things, can represent residents on a wider forum and help them achieve their goals, participates in the process of planning projects, activation programs, as well as strategies for solving social problems (Bąbska, Dudkiewicz, 2014: 18). The standard of community organisation run by the Municipal Social Welfare Centre was implemented, among other places, in one of the housing estates in Katowice. The local community organiser got to know the needs of the residents, determined what was most important to them, what was missing and what they would like to change in the first place. It turned out that the playground was of primary importance. Since the problems related to excessive alcohol consumption were one of the issues faced by the residents of the housing estate, this topic was also addressed and a sober lifestyle was promoted. The campaign was joined by institutions and non-governmental organisations. When the local activities had already started, it turned out that a lot of things could be done. A volleyball field, a housing estate club and an association were established. As the locals themselves say: "Much has changed in people's mentality, in their perception of their surroundings and the environment." Another initiative was held in Warszawa in the form of Neighbourhood Backyard Meetings, in which residents, employees of the 
district's reading room, policemen, councillors, as well as employees of support centres took part. Earlier, the local community organiser talked to the residents and found out that they were very concerned about the safety of their backyards, streets, staircases, as well as about the fact that the youth just loiters after school and they do not know what to do with their time. Hence the idea of integration, because: "If the people do not know each other, then taking care of safety will not have the desired effect." Within the framework of these activities, the Dream Ladder - a place where residents can clip pieces of paper with their needs and expectations - was established. Of course, some will be implemented, while others will not, but dialogue has become a fact (Polskie podwórka, 2013).

Another example (where it all started with an artistic project and ended with a large social undertaking and cooperation of residents with many entities) is an extremely interesting "Hedgehog" campaign, carried out as part of the aforementioned "Wrocław - entrance from the backyard" project. It all started with an attempt to activate the residents with a seven-metre-long hedgehog (a blow-up mascot consisting of a number of separate parts), prepared by culture animator Iza Rutkowska, who proposed a series of activities for both the younger and the older residents. Children were very eager to participate in the proposed activities (reading fairy tales, watching animations, art workshops and many more - all hedgehog-themed). A year later, on the initiative of an animator, the children went on a holiday trip with the hedgehog to the Hedgehog Rehabilitation Centre in Kłodzko. The project also resulted in a competition for residents, as part of which they could submit their proposals for actions to change, improve and revive the areas they lived in. For about a month, the participants could come and record their ideas in a place prepared for this purpose. Then all of them were displayed on the big screen and the voting started. While watching the recordings many people noticed that they do not know each other, despite living in such a close proximity. The most popular was the proposal to create a sports and recreation complex, which proved to be impossible to carry out on time. However, the neighbours made a decision to combine all the ideas and organised a fair, during which they prepared Christmas decorations and decorated the Christmas tree together. The decision was made to submit a project, not only for the recreation and sports complex, but also for the entire backyard, as part of the civic budget - this involved cooperation with city officials and the Wrocław Revitalisation. Since that day, the backyard has gained an informal name: The Backyard of All Residents. ${ }^{3}$

\footnotetext{
${ }^{3}$ Information from: http://izarutkowska.com/2018/09/14/przykladowy-projekt/, accessed: 30.05.2019.
} 
Another example, focused on assistance activities, was the "From Neighbours to Neighbours" initiative, which aims at building a long-term neighbourhood support network for older and sick people, in line with the principle: "Let us not forget about the other person."' The idea refers to the potential of self-help in the neighbourhood. It seems to be important for at least two reasons: the possibility of social activation of seniors whose health condition allows them to engage in such activities and the bond-forming nature of this form of support, which is important in intergenerational and intra-generational relations. "Bottom-up self-help activities are the most traditional and established practice of supporting older people. However, this support may also take another form - a regular neighbourhood service contracted by the municipality" (Koziarek, Sobiesiak-Penszko, 2015: 6).

It turns out that sometimes an idea can start to "live its own life" and bring its neighbours closer together, although at the beginning such an intention was not necessarily declared and taken into account at all. This happened in the case of mini-libraries. The first small wooden house was built by an American, Todd Ball, in memory of his deceased mother, a teacher and a book lover. He put it in place of a letterbox in his yard. It was supposed to resemble the school where she worked. Inside, he put his mother's favourite books so that anyone who knew and remembered her could take and read them. Friends and neighbours started to visit the mini-library, brought their own books, talked about the idea. It turned out that this was a good way to keep the tradition of reading printed books alive and an opportunity to bring people with similar interests together, make new acquaintances, make friends and integrate neighbours. ${ }^{5}$

Agnieszka Matan, in one of the radio programmes about neighbourly relations in the 21 st century, said that being local is now becoming fashionable, and that the thing that builds neighbourly integration is certainly a specific, common goal. (Jak wygladaja stosunki sasiedzkie w XXI wieku?) The Neighbour's Day has also gained in importance and popularity in recent years. It is an initiative of the European Federation of Local Solidarity (EFLS), which has already spread in many countries and is carried out every year on the last Tuesday of May. The idea comes from Paris, and Poland celebrated its neighbourhood for the first time in 2007. It is supposed to be a bottom-up activity. "It is not an event made 'for the people' but instead 'of the people' and 'by the people"'(Matan, Kopińska, 2010a: 37), which breaks the mould of the 'organiser-receiver' scheme. With the implementation of the idea in Poland, there was a revival resulting in the establishment of cooperation with enti-

\footnotetext{
${ }^{4}$ Information from: http://www.gotowidopomocy.pl/aktualnosci/sasiedzi-sasiadom-pomoz-seniorom-na-powislu-i-solcu/ accessed: 30.05.2019.

${ }^{5}$ Information from: https://kampaniespoleczne.pl/domki-dla-ksiazek/ [retrieved on: 30.05.2019]
} 
ties that "usually constituted autonomous parts of the neighbourhood and focused on performing their main tasks" - local shops, cafés, libraries, community centres.

Cafés and community centres are places where people, often neighbours from the same street, come together. Why not use this potential to build stronger neighbourly relations? (...) And yet, since the neighbours are already in a common, and more importantly neutral, space (...) why not use it to work together to revive the rest of the community and improve the quality of our life in the area?. (Matan, Kopińska, 2010b: 45 and 47)

The idea of an active neighbourhood therefore has advantages that cannot be overestimated. The effort to make it happen always pays off, because: "Neighbourhood is a great field for learning pro-social civic attitudes, an everyday school of citizenship (...) growing out of a sense of responsibility, caring for another person living next door, creating a neighbourhood community where certain rules are imposed, but others are already voluntarily shaped by the residents themselves" (Jordan, Konarzewska, 2015: 151).

\section{Conclusions}

In their analysis of a participatory budget, Agnieszka Naumiuk and Michał Bron Jr point out that:

A community of places and people cannot be 'created.' It is built out of everyday learning, experience and action. There is still much need for improvement, there are many inconveniences, frustrations and a lack of relevant research on the subject, but educators can be inspired by the fact that some people see their role and importance in social participation, they practice their agency, autonomy and independence on a local scale, putting into practice their individual and collective rights as a person who is not indifferent to the surrounding life. In this quest, they meet others, learn from them and influence them. (Naumiuk, Bron Jr, 2017: 51)

The cited examples are testimony to the fact that neighbourhood initiatives, by bringing out the inhabitants' potential and based on it, revive and change the places where people live, while the turn towards being more local takes place on many levels - everyday activities, often very informal, transformations in leaders' activities, and modifications to promotional strategies. It does not always bring visible and lasting results immediately, sometimes it requires long-term commitment, sometimes repeated small actions, encouraging, convincing, proving that it is worth it, repeating invitations to cooperate, because there are many barriers 
(both internal and external). However, it always makes sense because it allows for the development of creative and active attitudes (see also: Segiet, Słupska, 2018). Activities that aim at the revival of local communities can be initiated by a variety of actors and individuals. Sometimes people need encouragement to try, to start, to continue. Sometimes they do not quite believe in the power of the neighbourhood, but after the first steps they see that it simply works. To conclude, I would like to bring up a quote from the neighbourhood talks: "People may have thought that no one wants to integrate, meet, and it turned out that they want it and that there are more of them (...)" (Konarzewska, Kujawa, 2015: 9).

\section{Bibliography}

Bąbska B., Dudkiewicz M. (2014), Czym jest usługa Organizowania Społeczności Lokalnej (OSL)? [in:] M. Dudkiewicz, B. Bąbska, A. Skowrońska, Organizowanie społeczności lokalnej - usługa społeczna, Warszawa.

Bąbska B., Jordan P. (2014), Organizator społeczności lokalnej jako refleksyjny praktyk, [in:] T. Kaźmierczak, B. Bąbska, P. Jordan, M. Dudkiewicz, M. Mendel, M. Popłońska-Kowalska, Organizator społeczności lokalnej - refleksyjny praktyk, Warszawa.

CBOS (2017), Relacje sasiedzkie. No. 146/2017, ed. R. Boguszewski., https://cbos.pl/SPISKOM. POL/2017/K_146_17.PDF, accessed: 29.05.2019.

Chaskin R.J., Brown P., Venkatesh S., Vidal S. (2007), Budowanie potencjału społeczności lokalnej, trans. K. Kubin, I. Rybka, [in:] T. Kaźmierczak (ed.), Zmiana w społeczności lokalnej. Szkice o kapitale społecznym $w$ praktyce społecznej i nie tylko, Warszawa.

http://izarutkowska.com/2018/09/14/przykladowy-projekt/, accessed: 30.05.2019.

http://www.gotowidopomocy.pl/aktualnosci/sasiedzi-sasiadom-pomoz-seniorom-na-powislu-i-solcu/, accessed: 30.05.2019,

https://kampaniespoleczne.pl/domki-dla-ksiazek/, accessed: 30.05.2019.

Jakwyglądają stosunki sąsiedzkie wXXI wieku?, https://www.polskieradio.pl/8/404/Artykul/1625589,Jak-wygladaja-stosunki-sasiedzkie-w-XXI-wieku, accessed: 4.06.2019.

Jordan P., Konarzewska A. (2015), Edukacja w kierunku dobrego sąsiedztwa, [in:] R. Krenz, S. Mocek, B. Skrzypczak (eds.), Efekt motyla. Scenariusze rozwoju sektora społecznościowego w Polsce, Warszawa.

Kalita D. (2016), Sąsiedzkość jako narzędzie pracy z mieszkańcami [in:] D. Kalita (ed.), Międzypokoleniowe spotkania sąsiedzkie - przewodnik dla mieszkańców, Wrocław.

Konarzewska A., Kujawa O. (2015), Rozmówki sąsiedzkie, Warszawa.

Koziarek M., Sobiesiak-Penszko P. (2015), Jak dobrze mieć sąsiada. Od pomocy sąsiedzkiej do sąsiedzkich ustug opiekuńczych, Warszawa.

Matan A., Kopińska K. (2010a), Szansa dla warszawskiego podwórka, czyli o budowaniu sąsiedzkich więzi w stolicy, Animacja Życia Publicznego. Analizy i rekomendacje, no. 1-2.

Matan A., Kopińska K. (2010b), Wykorzystujmy zasoby, czyli kilka słów o lokalnej współpracy, Animacja Życia Publicznego. Analizy i rekomendacje, no. 3. 
Mojkowski K. (2012), Droga do sąsiada - rozmowa z Pawłem Jordanem, animatorem ruchu sąsiedzkiego, [in:] P. Henzler (ed.), Aktywni mieszkańcy. Inicjatywy sąsiedzkie w praktyce, Warszawa.

Naumiuk A., Bron M. Jr (2017), Budżet partycypacyjny w kształtowaniu wspólnej przestrzeni lokalnej - potencjał edukacyjny i inspiracje pedagogiczne, Pedagogika Społeczna, no. 3 (65).

Polskie podwórka. (2013), Informational and promotional supplement to Gazeta Wyborcza. 31 October.

Putnam R.D. (2008), Samotna gra w kręgle. Upadek i odrodzenie wspólnot lokalnych w Stanach Zjednoczonych, trans. P. Sadura, S. Szymański, Warszawa.

Radziewicz-Winnicki A. (2008), Pedagogika społeczna w obliczu realiów codzienności, Warszawa.

Romaszkan N. (2016), Wstęp, [in:] D. Kalita (ed.), Międzypokoleniowe spotkania sąsiedzkie - przewodnik dla mieszkańców, Wrocław.

Sąsiedztwa i mikroorganizacje w polskiej przestrzeni społecznej - próba diagnozy i rekomendacje (2009), Stowarzyszenie CAL Instytut Radlińskiej, Warszawa.

Schindler J. (2010), Konteksty aktywizowania społeczności lokalnych, [in:] B. Lewenstein, J. Schindler, R. Skrzypiec (eds.), Partycypacja społeczna i aktywizacja $w$ rozwiązywaniu problemów społeczności lokalnej, Warszawa.

Segiet K., Słupska K. (2018), Inicjatywy i ruchy sąsiedzkie, Pedagogika Społeczna, no. 4 (70).

Skinner S. (2014), Silniejsze społeczności. Jak budować potencjał społeczności i sektora publicznego, trans. A. Unterschuetz, Warszawa.

Skrzypczak B. (2014), Wstęp do serii ABS [in:] B. Bąbska, M. Rymsza, Organizowanie społeczności lokalnej - metodyka pracy środowiskowej, Warszawa.

Szczepańska M. (2018), Lokalna aktywność obywatelska - czynniki, pułapki, zróżnicowanie. O wzorach zaangażowania charakterystycznych dla wspólnot mieszkaniowych, Acta Universitatis Lodziensis. Folia Sociologica 64.

Toruńczyk-Ruiz S., Winiarska.A. (2018), Sąsiedztwo i różnorodność: perspektywa międzynarodowa, [in:] A. Górny, S. Toruńczyk-Ruiz, A. Winiarska (eds.), Po sąsiedzku z różnorodnością. Interakcje w miejskich przestrzeniach lokalnych z perspektywy różnych grup mieszkańców, Warszawa.

Wierzbicki Z.T. (1973), Aktywizacja i rozwój społeczności lokalnych, [in:] Z. T. Wierzbicki (ed.), Aktywizacja i rozwój społeczności lokalnych, Wrocław.

Wierzbicki Z.T. (1987), Aktywizacja i rozwój społeczności lokalnych i środowiskowych, Ruch Prawniczy, Ekonomiczny i Socjologiczny, no. 3.

Wolski A. (2016), Społeczność lokalna w objęciach globalizacji, [in:] D. Chojecki, E. Pierzchała, J. Wróblewska-Jachny (eds.), Tradycje i przyszłość badań nad społecznościami lokalnymi w naukach społecznych, Racibórz. 
